\title{
ANALISIS PENJUALAN DAN FAKTOR-FAKTOR YANG MEMPENGARUHINYA PADA USAHA INDUSTRI KECIL MEUABEL KAYU DI KOTA BANJARMASIN \\ Oleh:
}

Drs. Sulaiman, MSi

(Dosen STIMI Banjarmasin)

\begin{abstract}
This research is amed to do serve the sales development of wood furniture and to test the factors that influence it. Variables that are taste in thie research are variable $X_{1}=$ price level, $X_{2}=$ product amount, $X_{3}=$ product varity, $X_{4}=$ supply amount, and $X_{5}=$ sales promotion.

The sales development, if seen through index, show that in the year 2012, 15 (75\%0 of the samples gained the increase, hwile the rest suffered from sales decrease; then in the year 2013, 14 (70\%) of the samples gained sales increase, the rest 6 company suffered from sales decrease. If observed through the calculation the aggregate inkdex reached over 100\% in the year 2012 and 2013; this means that the sales of the whole company, used as research samples, increase than the previous year.

The result of variable test that used the $F$ test show that $F$ ratio $=13.401$, bigger than the table $F=2,71$; this means that the price level, product amount, product amount, supply amount, and sales promotion simultaneously give significant effects to the sales amount variable, as can be seen through the $p$ value, that $p(\alpha)$ value $=1.680 \mathrm{E}-08$ is lower than $p$ value $=0,05$.
\end{abstract}

Key words : sales amount, price level, product amount, production varity, supply amount, sales promotion

\section{PENDAHULUAN}

Perkembangan Industri Meubel di Kota Banjarmasin dewasa ini menun jukan perkembangan yang cukup menggembirakan, hal ini dapat dilihat dari bertambahnya usaha tersebut baik yang dikelola oleh perorangan maupun kelompok usaha. Perkembangan tersebut mendorong semakin meningkatkan usaha pemasaran khususnya penjualan, hal ini dikarenakan semakin berkembang usaha tersebut maka semakin bertambah pula pesaing-pesaing baru.
Persediaan yang tinggi memperlihatkan jumlah penjualan lebih kecil dari jumlah yang diproduksi, demikian juga sebaliknya bila tingkat persediaan kecil mencerminkan jumlah barang yang dijual hampir sama dengan jumlah yang diproduksi. Demikian pula tentang perputaran dana yang diinvestasikan pada persediaan barang dapat lebih cepat berubah dalam bentuk kas yang selanjutnya dapat dipergunakan untuk operasi usaha. Cepat lanbatnya perputaran persediaan menjadi kas akan sangat tergantung 
pada kebijakan penjualan (kredit atau tunai), bila penjualan secara tunai maka persediaan akan berubah langsung menjadi kas, dan bila penjualan dilakukan dengan kredit maka persediaan berubah menjadi piutang dan pada waktu jatuh temponya akan berubah menjadi kas. Bila dilihat secara teliti, bahwa perkem bangan usaha meubel kayu dalam pemasaran dan penjualannya tidak hanya ditentukan oleh unsur investasi dalam artian layak tidaknya usaha tersebut dari segi fuinansial, tetapi juga ditentukan oleh faktor lain seperti; jumlah produksi, harga produk, jenis produk, perkembangan perekonomian, meningkatnya pendapatan masyarakat, persaingan, dan lainnya yang dapat memberikan peluang dan ancaman bagi seorang pengusaha. Untuk memanfaatkan peluang yang ada, pengusaha atau seorang manajer memerlukan sejumlah usaha khususnya usaha pemasaran dalam bentuk strategistrategi pemasaran. Namun sebelum menentukan strategi tersebut perlu dilihat dan dianalisa penjualan yang telah dilakukan agar diketahui faktorfaktor apa saja yang mempengaruhi penjualan tersebut. Pada umumnya pengusaha mempunyai tujuan mendapatkan laba tertentu, mempertahankan atau bahkan berusaha meningkatkan unutk jangka waktu yang lama. Tujuan tersebut dapat terlaksana apabila penjualan dapat dilaksanakan seperti yang direncanakan. Dengan demikian tidak berarti bahwa barang yang terjual selalu akan menghasilkan laba. Disinilah faktor-faktor yang mempengaruhinya harus mendapat perhatian.

Menurut Basu Swastha (2010), tujuan akan menjadi kenyataan apabila dilaksanakan dengan kemauan dan kemampuan yang memadai, dan harus pula diperhatikan faktor-faktor lain seperti; modal yang diperlukan, kemampuan merencanakan dan membuat produk, kemampuan menentukan tingkat harga yang tepat, kemampuan memilih penyalur yang tepat, kemampuan menggunakan caracara promosi yang tepat, dan unsur penunjang lainnya.

Analisa penjualan yang dilakukan akan mendapatkan gambaran tentang produk, daerah penjualan, harga per satuan, jumlah penjualan, jenis produk yang terjual, banyaknya pesanan. Melalui studi kepustakaan dan penelitian lapangan dapat diidentifikasikan beberapa faktor yang dipandang berpengaruh terhadap penjualan, seperti; tingkat harga, jumlah produksi, jenis produksi, jumlah persediaan, dan promosi penjualan. 
Berdasarkan uraian tersebut dapatlah dirumuskan permasalahan dalam penelitian ini, yaitu bagaimana perkembangan penjualan, dan apakah faktor tingkat harga, jumlah produksi, jenis produk, jumlah persediaan, dan promosi mempunyai pengaruh terhadap jumlah penjualan pada usaha industri meubel kayu di kota Banjarmasin, serta dari faktor-yang mempengaruhi tersebut faktor manakah yang dominan pengaruhnya.

Hasil penelitian diharapkan dapat digunakan sebagai bahan informasi dan gambaran tentang tingkat penjualan dan faktor yang mempengaruhinya dalam rangka menyusun kebijakan dan strategi pemasaran dalam usaha meningkatkan jumlah penjualan dan mampu bersaing serta dapat berkembang bagi usaha industri meubel kayu di kota Banajarmasin.

Menurut Basu Swastha (2010) bahwa penjualan dikatakan sebagai ilmu dan juga dikatakan seni. Adanya penjualan dapat tercipta suatu proses pertukaran barang/jaasa antara penjual dengan pembeli. Dalam melakukan penjualannya, penjual dituntut untuk memliki bakat seni serta keahlian untuk mempengaruhi orang lain.

J. Supranto (2009) mengatakan bahwa analisa penjualan (sales analysis) adalah analisa sesungguhnya dari hasil penjualan (actual analysis of sales result), dimana analisa penjualan biasanya didasarkan atas 4 hal, yaitu; daerah (territory), produk (product), langganan (cunsumer) dan banayaknya pesanan (order size). Dari analisa dapat diketahui daerah yang kuat dan daerah yang lemah, jenis produk yang sangat menguntungkan dan kurang menguntungkan, para langganan yang mampu membeli, besarnya pesanan dan lain sebaginya. Keterangan tersebut memungkinkan perusahaan untuk mengkonsentrasikan usaha penjualan nya dimana memberikan hasil yang baik.

Penjual akan meminta harga jual yang lebih baik/tinggi dari yang diharapkan akan diterimanya, sedang kan pembeli akan menwar atau meminta harga yang ebih rendah dari yang diharapkan akan dibayarnya. Dengan tawar menawar mereka akan sampai pada suatu kesepakatan tentang harga. Dengan kata lain harga ditentukan oleh kekuatan antara pembeli dan penjual atau permintaan dan penawaran. Setiap tingkat harga jual akan membawa dampak nyang berbeda [ada tujuan yang berlainan, seperti keuntungan, hasil penjualan, dan bagian pasar.

Produksi adalah suatu proses transformasi dari bahan mentah menjadi 
barang jadi. Menurut T. Hani Handoko (2012) menyatakan bahwa dalam menentukan jumlah produksi dibuat dalam suatu skedul produksi yang memuat terperinci tentang apa dan berapa banyak perusahaan meren canakan untuk memproduksi masingmasing produk akhir dalam setiap periiode waktu (biasanya minggu) untuk beberapa bulan yang akan datang. Dan umumnya jumlah yang diproduksi dirumuskan seberapa banyak jumlah yang diminta dikurangi dengan tingkat persediaan yang ada.

Menurut Philip Kotler (2007) menyatakan produk adalah apa saja yang dapat ditawarkan ke dalam pasar untuk diperhatikan, dimiliki, digunakan atau dikonsumsi sehingga dapat memuaskan keinginan atau kebutuhan. Setiap produk selalu memiliki atribut yang berwujud, seperti mutu, ciri-ciri dan model. Gaya atau corak produk menunjukan perbedaan produk dibanding dengan produk pesaing.

\section{METODE PENELITIAN}

Variabel yang dianalisis terdiri dari variabel tergantung (dependent variable) yaitu pertama adalah jumlah penjualan yang disebut variabel $\mathrm{Y}$, kedua adalah variabel bebas (independent variable) yaitu faktorfaktor yang mempengaruhi penjualan, yang selanjutnya disebut variabel $\mathrm{X}$ (yang teridiri dari variabel $\mathrm{X}_{1}$ tingkat harga, $\mathrm{X}_{2}$ jumlah produksi, $\mathrm{X}_{3}$ jenis produk, $\mathrm{X}_{4}$ jumlah persediaan, dan $\mathrm{X}_{5}$ promosi penjualan.

Data yang dikumpulkan bersumber dari data skunder dan primer yang diperoleh dari perusahaan yang menjadi sampel dan instansi terkait yang berupa data kuantitatif dan kualitatif. Data yang dikumpulkan merupakan data tahun 2011, 2012, dan 2013. Adapun perusahaan yang menjadi sampel penelitiaan diambil berdasarkan purposive sampling (Masri Singarimbun dan Sofian E, 2009). Dari populasi diambil sampel sebanyak 20 buah perusahaan yang memenuhi kriteria yang ditetapkan.

Untuk melakukan analisis digunakan pendekatan kuantitatif dari model regresi berganda, sedangkan pengolahan data menggunakan analisa regresi berganda. Model tersebut dirumuskan: $\mathrm{Y}=\mathrm{b}_{0}+\mathrm{b}_{1} \mathrm{X}_{1}+\mathrm{b}_{2} \mathrm{X}_{2}+$ $b_{3} X_{3}+b_{4} X_{4}+b_{5} X_{5}+e_{i}$

Dimana;

$\mathrm{Y}=$ jumlah penjualan

$\mathrm{b}_{0}=$ konstanta

$\mathrm{X}_{1}=$ tingkat harga

$\mathrm{X}_{2}=$ jumlah produksi

$\mathrm{X}_{3}=$ jenis produksi

$\mathrm{X}_{4}=$ jumlah persediaan

$\mathrm{X}_{5}=$ promosi penjualan 
$\mathrm{e}_{\mathrm{i}}=$ variabel gangguan

$b_{1} \ldots b_{5}=$ koefisien regresi

Penggunaan model regresi

tersebut, haruslah memenuhi asumsiasumsi klasik yang mendasari model regresi, yang dalam ekonometri dinamakan Best Linier Unbiased Estimator/BLUE. (Djoko Mursinto, 2000)

Untuk membuktikan hipotesis pertama dihitung koefisien korelasi multiplenya dengan rumus (Sudjana, 1983), yaitu: $R=\sqrt{ }$ (JK.reg) $/ \Sigma Y^{2}$

Untuk membuktikan apakah koefisien korelasi multiplenya signifikan atau tidak dilakukan dengan uji F, dengan rumus sebagai berikut;

$$
\mathrm{F}=\left(\mathrm{R}^{2} / \mathrm{k}\right) /\left[\left(1-\mathrm{R}^{2}\right) /(\mathrm{n}-\mathrm{k}-1)\right]
$$

Hipotesis diterima bila $\mathrm{F}$ hitung lebih besar dari $\mathrm{F}$ tabel atau diperoleh harga $\mathrm{p}<0,05$. Sedangkan hipotesis kedua masing-masing koefisien regresinya diuji dengan menggunakan uji t, ( Sudjana, 1983);

$\mathrm{t}=\left[\mathrm{r}_{\mathrm{yi}} 12 . .(\mathrm{i}-1)(\mathrm{i}+1) . . \mathrm{k} \bigvee_{\mathrm{n}}-\mathrm{k}-1\right] /[\sqrt{ } 1$ $\left.\mathrm{r}_{\mathrm{yi}} 12 . .(\mathrm{i}-1)(\mathrm{i}+1) . . \mathrm{k}\right]$

Hasil uji $\mathrm{t}$ bermakna bila diperoleh $\mathrm{t}$ hitung lebih besar dari $\mathrm{t}$ tabel atau diperoleh harga $\mathrm{p}<0,05$, pengaruh yang dominan ditentukan oleh harga $\mathrm{p}$ yang terkecil atau $\mathrm{r}^{2}$ partial yang terbesar.

sebagai tahun dasar. Dilihat dari hasil tersebut

$$
\text { menunjukan }
$$

bahwa

\section{HASIL DAN PEMBAHASAN}

Hasil penelitian menunjukan bahwa perkembangan penjualan dari usaha industri meubel kayu yang dinyatakan dalam angka indeks, yaitu angka indeks sederhana dan angka indeks gabungan. Angka indeks sederhana menunjukan angka indeks masing-masing perusahaan yang menjadi sampel penelitian, sedangkan angka indeks gabungan menunjukan angka indeks seluruh perusahaan.

Berdasarkan perhitungan menunjukan bahwa angka indeks sederhana masing-masing perusahaan yang menjadi sampel penelitian pada tahun 2012 memperlihatkan 15 buah dari 20 buah perusahaan menunjukan angka indeks si atas $100 \%$, ini berarti jumlah penjualan dari masing-masing perusahaan mengalami kenaikan, sedangkan 5 buah di bawah 100\%, berarti mengaalami penurunan penjualan. Kemudian pada tahun 2013 sebanyak 14 buah atau $70 \%$ dari sampel menunjukan angka indeks di atas $100 \%$, berarti mengalami kenaikan penjualan, sedangkana sisanya sebanyak 6 buah perusahaan mengalami penurunan penjualan dibanding dengan tahun 2011

perkembangan penjualan pada tahun 2012 mengalami kenaikan sebanyak 15 
buah, sedangkan pada tahun 2013 yang mengalami kenaikan penjualan sebanyak 14 buah.

Bila dilihat dari perhitungan angka indeks gabungan menunjukan bahwa baik pada tahun 2012 maupun tahun 2013 menunjukan angka indeks di atas $100 \%$, ini menunjukan bahwa secara keseluruhan perusahaan yang menjadi sampel penelitian penjualannya meningkat dari tahun sebelumnya.

Hasil perhitungan regresi berganda untuk mengetahui pengaruh variabel-variabel yang diteliti terhadap penjualan diperlihatkan seperti pada tabel berikut ini:

Tabel

Hasil Perhitungan Regresi Berganda dari Variabel yang Bepengaruh Terhadap Jumlah Penjualan pada Uasaha Industri Meubel Kayu di Kota Banjarmasin

\begin{tabular}{|c|l|r|r|r|r|c|}
\hline No. & \multicolumn{1}{|c|}{ Variabel } & \multicolumn{1}{c|}{ Koef.Reg. } & \multicolumn{1}{c|}{ T hitung } & \multicolumn{1}{c|}{ Prob. } & $\mathrm{r}^{2}$ parsial & Ket \\
\hline 1. & $\mathrm{X}_{1}$ Tingkat harga & 179.5675 & 3.159 & .00259 & .1560 & $\mathrm{~S}$ \\
2. & $\mathrm{X}_{2}$ Jumlah Produksi & 678.7110 & 4.462 & .00002 & .2852 & $\mathrm{~S}$ \\
3. & $\mathrm{X}_{3}$ Jumlah Produk & -5448.7333 & -3.229 & .00212 & .1618 & $\mathrm{~S}$ \\
4. & $\mathrm{X}_{4}$ Jumlah Persediaan & 512.3596 & .739 & .46296 & .0100 & $\mathrm{TS}$ \\
5. & $\mathrm{X}_{5}$ Promosi Penjualan & 3384.5101 & 1.745 & .08676 & .0534 & $\mathrm{TS}$ \\
6. & Constanta & -12066.2026 & & & & \\
\hline
\end{tabular}

$\begin{array}{llll}\text { R Square } & =0.5537 & \text { F ratio } & =13.401 \\ \text { Multiple R } & =0.7441 & \text { Probabilitas } & =1.680 \mathrm{E}-08 \\ \mathrm{~S} & =\text { signifikan } & \text { TS } & =\text { tidak signifikan }\end{array}$

Hasil regresi menunjukan bahwa koefisien korelasi multiplenya sebesar 0.7441, ini berarti variabel harga, jumlah produksi, jumlah produk, jumlah persediaan, dan promosi penjulan mampu menjelaskan variabelitas tingkat penjualan $(74,41 \%)$, sedangkan $25,59 \%$ dijelaskan oleh variabel lain yang tidak dimasukan dalam model. Kemudian untuk membuktikan hipotesis pertama dilakukan dengan uji F, yang hasilnya menunjukan bahwa $\mathrm{F}$ rasio $=13,401>$ dari $\mathrm{F}$ tabel $=2,71$ ini berarti bahwa secara bersama-sama variabel harga, jumlah produksi, jumlah produk, jumlah persediaan, dan promosi penjualan mempunyai pengaruh yang signifikan terhadap variabel jumlah penjualan, demikian pula dilihat dari nilai $\mathrm{p}(\alpha)$ $1.680 \mathrm{E}-08<$ nilai $\mathrm{p}=0,05$.

Hipotesis kedua yang menyatakan bahwa variabel yang 
dominan pengaruhnya nterhdap penjualan adalah jenis produksi ternyata tidak terbukti, hal ini ditunjukan bahwa hasil uji t ternyata variabel $\mathrm{X}_{2}$ jumlah produksi yang emmpunyai nilai t hitung terbesar $(4,462)$ dari variael lainnya dan juga nilai $r$ parsialnya terbesar $(0,2852)$ dan nilai p yang terkecil yaitu 0,00002 .

Berdasarkan data yang telah didapat dan diolah menunjukan bahwa penjualan yang dilakukan oleh usaha industri meubel kayu di kota Banjarmasin menunjukan jumlah yang meningkat dengan asumsi tahun dasar pembanding adalah tahun 2011. Seperti pada tahun 2012 jumlah penjualan dari usaha ini meningkat yang diperlihatkan dari angka indeks gabungan sebesar $104,30 \%$, demikian pula pada tahun 2013 angka indeks gabungan sebesar $113,48 \%$. Hasil menggambarkan bahwa kondisi yang cukup menggembirakan karena usaha industri meubel ini tetap eksis dalam usahanya walaupun bahan baku kayunya sangat terbatas.

Kemudian dilihat dari variabel yang dapat mempengaruhi tingkat penjualan menunjukan bahwa variabel harga yang ditawarkan oleh usaha tersebut mengalami perubahan (penurunan harga). Sesuai dengan teori bahwa permintaan barang/jasa meningkat bilamana harga dari barang/jasa tersebut turun.
Jumlah produksi masing-masing usaha tersebut berubah naik atau turun, dan ada juga sebagian yang tetap dengan jumlah yang sama. Pada tahun 2012 sebanyak 8 (delapan) usaha yang mengalami kenaikan jumlah produksinya atau $40 \%$ dari jumlah sampel, demikian pula yang menurun sebanyak 40\%, dan sebanyak 4 buah dengan jumlah produksi yang sama.

Jenis produksi yang dibuat bervariasi artinya jumlah jenis produksinya antara 1 sampai dengan 4 jenis, hal ini memberikan pilihan bagi konsumen untuk membeli sesuai dengana selera.

Perubahan tingkat persediaan dari 20 buah usaha yang menjadi sampel, sebanyak 14 buah usaha menunjukan kenaikan persediaan dan sebanyak 6 buah usaha mengalami penurunan persediaan, hal ini disebankan oleh penualan yang menurun dan jumlah produksi yang bertambah.

Kegiatan promosi yang dilakukan dihitung dalam jumlah kali mengikuti atau melakukan atau ikut dalam promosi penjualan, yaitu rata-rata usaha melakukan kegiatan promosi 1,5 kali dalam satu tahun. Usaha promosi ini dirasa masih kurang yang mengabkibatkan kurangnya informasi 
kepada calon konsumen tentang barang yang dibuat dan dijual.

Dari perhitungan regresi berganda menunjukan bahwa walaupun secara bersama-sama menunjukan signifikan pengaruhnya dari variabel harga, jumlah produksi, jenis produk, tingkat persediaan, dan promosi penjualan, namun dilihat secara parsial hanya 3 (tiga) variabel yatitu $X_{1}$ tingkat harga, $X_{2}$ jumlah produksi, dan $X_{3}$ jenis produk yang signifikan pengaruhnya terhadap penjualan, sedangkan dua variabel lainnya yaitu variabel $\mathrm{X}_{4}$ tingkat persediaan dan $\mathrm{X}_{5}$ promosi penjualan tidak signifikan pengaruhnya terhadap tingkat penjualan. Hal ini bisa saja terjadi mungkin disebabkan bahwa konsumen atau calon konsumen sedah mengetahui produk dan jenis produk serta harga yang berlaku untuk barang tersebut, sehingga promosi tidak begitu berpengaruh terhadap minat konsumen untuk membeli meubel tersebut. Demikian juga variabel yang dominan pengaruhnya ternyata jumlah produksi, yang semula diduga adalah jenis produk, hal ini juga dapat disebabkan oleh sedah diketahuinya jenis produk tersebut yang merupakan ciri khas dari daerah.

\section{SIMPULAN}

Jurnal Risat Inspirasi Manajomen dan Kawirausahaan
Dari hasil penelitian dan analisa menunjukan bahwa tingkat penjualan dari usaha ini bervariasi dan memperlihatkan kenaikan secara keseluruhan yang ditunjukan dari angka indeks gabungan dan hal ini menggambarkan bahwa usaha tersebut dapat bertahan dan dapat berkembang pada masa yang akan datang. Kemudian analisis dari variabel yang mempengaruhinya menunjukan bahwa secara bersam-sama mempunyai pengaruh yang signifikan, sedangkan bila dilihat secara parsial ada dua variabel yang tidak signifikan pengaruhnya. Variabel yang dominan yang semula dinyatakan adalah variabel jenis produksi, ternyata variabel jumlah produksi yang mempunyai pengaruh dominan terhadap tingkat penjualan.

Berdasarkan analisis tersebut diharapkan para pengusaha atau pemilik dapat mempertimbangkan faktor yang berpengaruh terhadap tingkat penujualan agar supaya perkembangan usaha tetap maju dam mapu bersaing, yaitu dengan melihat kemajuan teknologi, model dan permintaan pasar sertaa keinginan konsumen. Demikian pula diusahan membentuk suatu wadah agar pengusaha tidak ketergantungan dan kehabisan bahan baku yang sekarang ini sudah sulit didapatkan. 


\section{DAFTAR PUSTAKA}

Handoko, T Hani, 2012, Dasar-Dasar Manajemen Produksi dan Operasi, BPFE UGM, Yogyakarta.

Kotler, Philip, 2007, Manajemen Pemasaran (Analisis, Perencanaan dan Pengendalian), Erlangga, Jakarta.

Mursinto Djoko, 2000, Ekonometri Salah Satu Alat Analisis Ekonomi, FE-Unair, Surabaya.

Riyanto Bambang, 2010, Dasar-Dasar Pembelanjaan Perusahaan, Edisi Ke Tiga, Cetakan Keduabelas, Yayasan Penerbit Gajah Mada, Yogyakarta.

Singarimbun Masri dan Sofyan Effendi (Penyunting) 2009, Metode Penelitian Survey, LP3ES, Jakarta.

Supranto J., 2009, Teknik Riset Pemasaran dan Ramalan Penujualan, Edisi Revisi, Cetakan Pertama, Rineka Cipta, Jakarta.

Swastha Basu, 2010, Manajemen Penjualan, Edisi Ketiga Cetakan Kelima, BPFE UGM, Yogyakarta. 